\title{
The Dutch Sociology of Education: its origins, significance and future
}

ANTON WESSELINGH, Department of Educational Sciences, University of Nijmegen, The Netherlands

ABSTRACT As in many other countries the Dutch sociology of education has blossomed into a fully-fledged specialised branch of sociology since the beginning of the 1970s. A tradition of policy-oriented research has also consolidated the position of the sociology of education at the universities. The strength of this relatively small group of specialists lies in the solid empirical basis and use of advanced research techniques and analyses in their woork. Theory and reflection are not the strongest qualities of this group. A good organisational structure naturally helps keep the ranks closed. Recently, however, marginalisation of the specialism is threatening because of isolation from general sociology. Mainstream educationalists and policy-makers are also challenging the sociologists of education to make their contribution more explicit than ever.

\section{Introduction}

There is widespread consensus on the sociology of education being first and foremost a specialism in the general field of sociology. The basic assumptions, perspectives and methodologies of this discipline are therefore employed. In the Netherlands, moreover, sociology bears the landmarks of national developments and problems and the growth in this field can be seen as a specific answer to these problems. Dutch sociology-and the sociology of education-can also be seen as a product of international developments. Both national and international contexts thus shape the place of sociology of education in any country.

In this paper, a short history of the Dutch sociology of education will first be presented. Some current themes in the Dutch sociology of education will then be considered and followed by a few conclusions and further discussion.

\section{Origins and Development of Dutch Sociology of Education}

The origins of the sociology of education in the Netherlands can be situated within the academic field of sociology which was firmly settled with the establishment of separate 
faculties in the universities in the 1960s. Dutch sociology may roughly be characterised as empirical in its orientation, strongly related to social policy and averse to large-scale modelling and 'grand theories'. There is a clear preference for theories of the middlerange and a great deal of influence from abroad with regard to both theory and methodology. The influence of such theorists and researchers as Coleman, Jencks, Giddens, Bourdieu, Boudon, Bernstein, Habermas, Blau and Duncan is evident. At the moment, Dutch sociology appears to be fragmented into two different schools of thought, both with their own networks [1]. Sociology of education is one of the several specialisations within the field of sociology.

\section{Origin}

The ups and downs of the Dutch sociology of education should be seen not only in relation to general sociology but also in relation to other social sciences and, most notably, pedagogical science. The impact of both perspectives on the development of the sociology of education in the Netherlands will thus be considered in this paper.

As in most European countries and the US, sociologists in the Netherlands have only recently shown a systematic and empirical concern with matters of education and general socialisation. The first few research projects were only undertaken in the 1950s (Matthijssen, 1958; Matthijssen \& Sonnemans, 1958) and it was not until 1964 that Dutch sociologists officially showed an interest in the subject with a conference from the Netherlands Sociological Society devoted to the basic problems of the sociology of education (NSV, 1965). On the whole, the sociological interest in education and schooling lagged behind the fast-growing interest in general sociology and such subdisciplines as the sociology of industrial relations, the sociology of organisations, political sociology, the sociology of religion and the sociology of the family. Priority appears to have been given after World War II to the repair and development of the other more vital sectors of society, for example economic activities and their scientific back-up. Other disciplines, such as pedagogy and psychology had traditionally laid claims to the field of education, however, and the sociologists were forced to distinguish their specific contributions with the risk of major boundary disputes. Finally, education has long been regarded as a purely pedagogical or didactic field and not, in contrast to other aspects of society, as a social problem or matter of social policy (Wesselingh, 1982, p. 320).

In 1968, the first European Conference on the sociology of education was organised in the Netherlands (Noordwijk aan Zee) with many outstanding colleagues from Europe attending (Matthijssen \& Vervoort, 1969). This initiative was repeated once in Austria and then came to an end.

\section{Social Stratification and the Sociology of Education}

Frederik van Heek (1907-1987) was the holder of the first chair in empirical sociology at the University of Leiden in 1948. He was the first sociologist in the Netherlands to raise the issue of social mobility in a stratified society. For this purpose, he constructed a scale to measure occupational prestige, consisting of a hierarchy of occupations ranked according to the social prestige attributed to each by a panel of judges and the public at large. The work of Van Heek and his team was so successful that it came to be referred to as the Leiden School (also in international circles). From the start Van Heek was preoccupied with the opportunities for upward social mobility. It should therefore 
come as no surprise that the problem of equal opportunities eventually led him to the educational system as one of the main avenues for social mobility.

In the context of this paper, the last great research project from the Leiden School is the most relevant: the so-called Talent Project. This project consisted of several smaller research projects undertaken between 1961 and 1968. The main question was: which social factors obstruct the participation of gifted or talented children from the lower classes - and most notably the working-class children -in the higher levels of the Dutch educational system?

The Talent Project was very important for the development of the sociology of education for a number of reasons. First, the main research question inspired several researchers to raise further research questions (e.g. Vervoort, 1968; Van Calcar et al., 1968; Peschar, 1975; Meijnen, 1977). The Talent Project has thus been not only the most important impulse for sociological research into the problem of inequality in education but also an inspiration for the development of the specialism in general. Second, the results of this project have had an enormous influence on the educational policy of the Dutch government. This influence started with the first measures to combat the educational disadvantages experienced by lower-class children and continues with the provisions in educational priority areas for lower-class and immigrant children. The Talent Project thus stimulated the establishment of strong ties between sociologists of education and educational policy. Third, the project proved to be fruitful for the development of new educational research methods in part as a result of the critical conceptual and methodological debates around the final report (Van Heek et al., 1968).

To this day, research into the problem of educational inequality is one of the strongest research traditions in the Dutch sociology of education and has resulted in the establishment of a society for the advancement of research into education and social inequality (in Dutch: OOMO). This society has its own infrastructure and its own series of publications. More generally, the strong position of the social stratification research at the Leiden School has helped develop the sociology of education, a young specialism which could use the solid backing of a respectful research tradition. The sociology of stratification legitimises a specialism operating in a sector of society, education, which does not appear to be very attractive to social scientists in general.

\section{Educational Sciences and the Sociology of Education}

A second important impulse for the development of the sociology of education in the Netherlands came from the educational sciences and one of its professional practitioners, Philip J. Idenburg (1901-1995). Idenburg is the former holder of a chair in pedagogy and education at the University of Amsterdam and taught 'the social context of education including the comparative study of education'. Before his professorate, Idenburg had been the managing director of the Central Bureau for Statistics and held top positions in the government administration, (e.g. Director-General of the Ministry of Education). Idenburg thoroughly analysed the social context of education and the educational system (1964, 1971). He published on a wide range of themes: from educational policy, the history of education and educational economy to education and social change and education in developing countries. As one of the last generalists he succeeded in translating many sociological insights into solid studies of educational policy and comparative education. Several of his concepts and terms are now quite common in the educational literature (e.g. his concepts of 'distributive' and 'constructive' educational policy). 
The influence of this eminent educationalist can only partly be traced to the actual situation of the educational sciences in the Netherlands. This is a result of the high level of specialisation within the educational sciences (making generalists of the calibre of Idenburg very rare), the under-development of comparative and historical studies in education and the almost complete neglect of the economy of education as a field of study. The educational-science agenda consists of the problem of educational optimalisation, the search for effective schools and concern for the quality of the educational output (to mention only a few headlines). Modern educationalists seem to have drifted away from classical educational theory in the direction of an overwhelmingly empirical and methodological orientation. They also appear to have limited themselves to the institutionalised system of education (regular education) and even to some specific sectors such as industrial training courses. It is in fact the sociology of education that has taken over Idenburg's broad orientation in analysing the relationship between education and society. The status quo is continually questioned in order not to simply 'take' educationalists problems but instead to 'make' their own (Young, 1971). In many of the interdisciplinary departments of education in Dutch universities, it is the sociology of education that has the most reflective, critical attitude towards its object of study. Sociologists of education try to keep a view of the whole, which must then be defended against the tendencies towards differentiation and fragmentation and an education policy that fosters piecemeal engineering and ad hoc policy measures.

\section{routh Studies}

Although situated at the margin of the pedagogical sciences, studies of youth and their behaviour can surely be classified as one of the impulses for the development of the sociology of education in the Netherlands. The modernisation of post-war society, as a result of processes of industrialisation and urbanisation was observed by the authorities with great concern. In their opinion, World War II had set a process of demoralisation in motion: there was a growing decay of norms and values intensified by the disintegration and erosion of traditional societal institutions such as the family and various youth organisations. Society was becoming a mass society and increasingly more commercialised and depersonalised. Young people were argued to be the victims of this process and so the problem of lawlessness was stated in terms of 'mass youth' or 'inner-city kids'. In order to get a better grip on this problem, the government called for a large-scale investigation into 'the origin and consequences for the mentality of the so-called mass youth'. This can be seen as a historic moment because the social sciences were called upon to help solve a social problem for the first time in the Netherlands. Large-scale projects were set up by several research institutes with the co-operation of educationalists, psychologists and sociologists.

The series of research projects devoted to 'the anti-social youth' has not been systematically continued. The connection of these projects to the sociology of education and their significance for the growth of this field are therefore more indirect than in the case of social-stratification and comparative-education research. Schools also hardly entered the picture in these studies. After a break of several years, however, youth studies have actually come to constitute a solid specialism at the Universities of Utrecht and Leiden in particular. Education and the transition from school to work are also now significant issues (Van der Linden, 1991). 


\section{A Blossoming Specialism}

As a description of the themes in the next section of this paper will show, the sociology of education reached its height in the 1970s. The range of interests broadened considerably to include such topics as the sociology of the curriculum, effective schools, research into educational priority areas, school-attainment research, new debates on 'deschooling' and cultural literacy. The range of theoretical options also grew as a result and is reflected by increased attention to conflict theory, interpretative sociology, the sociology of knowledge and so forth. Other theories and schools of thought, on the other hand, have become rather marginal: socio-linguistics and mass communication, for example.

The arsenal of research methods has also been greatly enlarged. On the one hand, there are increasingly sophisticated quantitative techniques and multi-level analyses; on the other hand, there are more and more qualitative techniques including observation, content analysis, depth interviews and so forth.

The Dutch sociology of education has not been untouched by the general crisis in the $1980 \mathrm{~s}$ in the social sciences and sociology in particular. This crisis occurred all over the world and has decreased the role of sociology in the public debate, including educational matters. The Dutch sociology of education managed to survive this crisis because of its solid empirical basis and a certain degree of scientific consensus which appears to have remained intact despite the differences in orientation and opinion in the area. The Dutch sociology of education has also been consolidated into a sturdy organisational structure which has proved to be quite helpful in hard times.

\section{Themes and Topics in the Sociology of Education [2]}

\section{Characteristics of Systems and Schools}

Following American studies, the work of the aforementioned Idenburg and, more recently, the work of Bourdieu, Dutch sociologists of education have studied the use different social groups have made of the educational provision in higher education (i.e. the formation of elites in society) (Beekenkamp \& Dronkers, 1984). Also studies into the rise of mass education by historians and sociologists have produced a wealth of material (Boekholt \& De Booy, 1987; Veld, 1987; Wolthuis, 1987; Lenders, 1988; De Swaan, 1988; Van der Ploeg, 1993), which gives us an opportunity to discuss the work of such American and British sociologists as Boli et al. (1985), Ramirez \& Boli (1987) and Turner (1986).

Differences between Schools. Under the heading of the characteristics of schools and school systems, the question of differences between schools arises and at least three topics have been studied by Dutch educational sociologists. Coleman's survey (1966) and its conclusions about the minor effects of schooling relative to family characteristics and the social background of the students, set the tone for quite some time. On the basis of this and other research from the US and Britain, Meijnen (1984) went on to investigate the effects of schooling, by looking at different forms of educational organisation, for instance in schools with heterogeneous or homogeneous pupil populations. This kind of research has contributed to school effectiveness studies (Scheerens, 1989).

A second topic is based on the work of Bourdieu (1964, 1970, 1979). Research by Rupp \& De Lange (1989) has shown the market position of primary schools to depend in part on the type of secondary education for which the primary school is supposed to 
prepare its pupils, in particular on the educational status of that particular institution. A number of submarkets can also be distinguished here. For example, culturally-oriented Montessori schools can be distinguished from other primary and secondary schools and compared to more economically-oriented schools (Kalmijn \& Batenburg, 1986; Rupp $e t$ al., 1990).

A third topic consists of the differences between private and public schools, once again following Coleman (Coleman et al., 1982; Coleman \& Hoffer, 1987). The question here is which type of school is more effective. Dutch research into the effects of the three main types of education (public, Protestant or Catholic) has been concentrated on the identities of the schools and the success of their pupils during primary and secondary education (Van Laarhoven et al., 1986; Costongs \& Dronkers, 1989; De Jong \& Roeleveld, 1989; Dijkstra, 1992; Vrecburg, 1993).

Differences Within Schools. This kind of research has developed quite significantly in the Netherlands over the past decade and Jungbluth (1985) in particular has focused on the educational inequality found in schools. According to Jungbluth, the way in which a pupil is perceived-combined with sex and social background-determines the education which is offered. The teacher's expectations with regard to a pupil's achievement, for example, have been shown to be very important for the kind of secondary education which the student will attain. Differences in social background are translated into a sexand class-specific view of the pupils and thus transformed into educational inequality (Van der Kley, 1983; Van der Hoeven-Van Doornum, 1990). Educational inequality is thus seen as the result of negotiations in the classroom over the definition of the situation, which is also crucial to attribute an educational identity to the pupils. The influence of interpretative theories such as, for instance, symbolic interactionism and ethnomethodology, is evident here. An important notion is also the shift from a social identity to an educational identity through the processes of labelling and stigmatisation. This final identity has been shown to be decisive with regard not only to a pupil's school career but also to his or her future success in the labour market.

\section{Family Characteristics}

Research into the relation between the social environment and the school career was one of the earliest activities of the Dutch sociologists of education. 'Home and school' has been an attractive theme since the end of the 1950s. In this kind of research parental employment (often the father's job) and/or parental education and/or parental income are usually taken as a measure of 'social environment'. That is, socio-economic status (SES) is measured in a traditional manner.

Stratifications in a society may vary according to the country and may change over the course of history (Ultee, 1984). The 1970s and 1980s saw new dichotomies arise within the traditional occupational stratification. When the effects on the educational opportunities of their children were analysed for people with and without a job (and thus dependent on social security), however, the old dichotomy of highly- and less-educated parents still appears to be relevant (Te Grotenhuis, 1994). Another dichotomy is that between single- and two-parent families and the consequences of this situation for the educational opportunities of their children (Bosman, 1993): the negative effects of a single-parent home are still quite small when compared to such traditional factors as parental education. A third new dichotomy is manifesting itself with regard to immigrants and already-established Dutch citizens. One of the main disputes concerns the 
importance of various factors in explaining the limited educational opportunities for the children of immigrants. Once again, the largest part of the observed differences in educational opportunity appears to stem from such traditional factors as parental education and occupation and not from ethnicity as such (Van 't Hof \& Dronkers, 1993; Fase, 1994).

In empirical studies, the relevance of different socio-economic conditions, different socio-cultural conditions and different values and norms for the observed differences in school careers has been considered. A clear picture has gradually emerged, moreover. Social background appears to influence the level of educational attainment mainly through cultural-educational patterns, while financial resources have become less significant. As Bourdieu has shown, a distinction between culturally- and economicallyoriented families exists in every social class. These orientations lead to a choice of different schools and educational routes (Kalmijn \& Batenburg, 1987; Rupp \& De Lange, 1989).

\section{Social Inequality, Education and Language}

One of the central issues in early research into educational inequality was the development and use of language among (young) children. Mastery of the standard language or the language of the dominant social group was supposed to be a sine qua non for doing well at school and thus for the attainment of a high level of education. Considerable attention was paid particularly to the relationship between language use and social class during the 1970s as a result of the emergence of the field of socio-linguistics (Appel et al., 1976; Lenders et al., 1978). Basil Bernstein's work on socio-linguistics was particularly important in this respect. The relation between language use and social inequality has been analysed in the Netherlands by Huls (1982). Using Bernstein's theoretical framework and participant observation of the verbal interactions in two Dutch families from working-class and upper-class backgrounds, Huls found only partial support for Bernstein's theory.

The issue of language mastery has changed over the years in the Netherlands. Until the 1970s, it was relevant only for native speakers of language varieties or dialects other than standard Dutch: the non-native speakers of standard Dutch fell within the boundaries of a single national culture. The situation changed, however, with the rise of immigration and a multi-cultural society in the Netherlands. Language acquisition by pupils from ethnic minorities and bilingualism became important topics for Dutch research (Appel, 1984). As with the period of socio-linguistic research in the 1970s, two camps are likely to arise, with fundamentally different views on how to tackle the problem of ethnic communities and language development. While it is beyond the scope of this paper to survey the discrepancies, the division seems to be between those in favour of assimilation to what is taken to be Dutch mono-culture (De Jong, 1987) and those who define the problem in terms of ethnic relations and favour the rise of a multi-cultural and accommodating society in the Netherlands (Leeman, 1985). This division is also closely related to the relative importance of ethnic culture and more traditional factors such as parental education and parental occupation for unequal educational opportunities (cf. Fase, 1994). 


\section{Education and Life Chances}

Education is of major importance for allocating 'Lebenschancen' (Weber, 1956). The members of different social classes have differential access to the relatively scarce means in a society and consequently come to occupy different social positions. Statements about the prominent role of schooling in society have become so common in the sociology of education that things appear to have grown out of proportion. The importance of education has become somewhat over-stated over the last few decades: other socialising institutions such as the family, peer groups and the media also play their part, which means that the school by no means has exclusive influence over the child. Furthermore, education varies in significance and meaning according to social group. History shows, for example, that economic elites utilise the existing educational facilities on a very selective basis. The role of education in the formation of elites in society is an important theme for research although it is underdeveloped in the Netherlands when compared to other countries (Beekenkamp \& Dronkers, 1984). One explanation for this underdevelopment could be the non-existence of institutionalised Dutch elite schools or universities, compared to other European societies. The rise of schools with an international curriculum for Dutch pupils may represent a step in the direction of elite education in the Netherlands, as part of the integration of a relatively small nation into the larger European Community (Dronkers, 1991).

There is a prominent tradition of research and theory in the Netherlands with regard to the relation between education and the labour market, education and marital chances, education and health and so forth. Vervoort (1981) and others have put the role of education into the theoretical perspective of reproduction by showing the relevance of the labour system to the allocation of life-chances (Van Hoof \& Dronkers, 1980; Van Hoof, 1987). In these studies, the way in which the labour market mediates between the educational and labour systems has been highlighted. Work by Van Hoof and Dronkers has also left its mark on research into the relation between educational and occupational attainment (Diederen, 1987; Meesters, 1992). In this empirical research, the transition from school to work is considered in terms of social background, scholastic ability, level and type of education and level and type of job.

The results of large-scale investigations across a number of regions were also very interesting with regard to the relation between education and life-chances (cf. Vliegen \& De Jong, 1981). Differences in the participation in secondary education seem to be connected to the quality of a region as measured by economic strength, housing situation and other facilities. Work by Glebbeek \& Mensen (1986) and by Glebbeek (1993) is also related to this topic. In their neo-Weberian orientation which seems to be primarily inspired by Parkin (1971), they empirically attempt to specify the market conditions which foster a reproductive or emancipatory role for education. In this research, the manner in which the educational level of employees influences the selection criteria used by employers is described. Further work along these lines may provide greater insight into the connection between education, labour and stratification/inequality.

Apart from the issue of education and labour, there is also the issue of education and cultural participation. This theme is closely related to part of the work of Pierre Bourdieu and his work on the formation of social elites in France $(1964,1984,1989)$. Ganzeboom (1988) along with Ganzeboom \& De Graaf (1990) have considered this theme for the Netherlands where participation in culture is independently influenced by education, individual ability, individual social class, parental social class and cultural orientation. One conclusion is that the ideas of Bourdieu appear to be only partly relevant for Dutch society. 


\section{Research on Educational Attainment}

Research into social stratification and social mobility inspired early research into educational opportunities. As already mentioned, Van Heek, one of the founding fathers of the Research Committee on Social Stratification and Mobility of the International Sociological Association (ISA), led a group devoted to this topic. Van Heek's most relevant study entitled 'Hidden Talent', can easily be compared to other well-known studies in western Europe (e.g. Halsey et al., 1961). The conclusions of this study produced a period of internal reflection and dispute, particularly with regard to the role of education in the reproduction of social inequality (Wesselingh, 1979, 1985). This debate had its roots in British and American sociological theory and research. Results such as those of Jencks (1972) in the US were easily used by Dutch politicians to disqualify the educational reforms proposed by the socialist Minister of Education Van Kemenade (who was also a prominent sociologist of education). The reforms were aimed at the introduction of comprehensive secondary education in the Netherlands and were comparable to the reforms in Sweden, the Federal Republic of Germany, Austria, Belgium, Scotland, England and Wales. The debate with regard to Jencks' results has stimulated attempts at replication in the Netherlands (Dronkers \& De Jong, 1979; Dronkers \& Bakker, 1989) and a fruitful line of research. The availability of several good longitudinal datasets on educational and occupational attainment, analysed in a rather sophisticated way, has produced improved indicators of social background (Dronkers, 1990) and better comparisons across time and space for international cohorts (Schijf \& Dronkers, 1989; Peschar, 1990).

\section{Conclusions and Discussion}

Starting in 1945, a strong connection existed in the Netherlands between social research and policy. In the field of education, this lasted until the 1970s when a more critical sociology of education - comparable to the 'new sociology of education' in the UK-presented itself as an alternative to the mainstream sociology of education, which insufficiently analysed the ideological assumptions behind the selection and organisation of knowledge (Young, 1971). In contrast with the situation in the UK, however, the Dutch sociology of education has no roots in the curriculum of the teacher-education colleges.

In the Netherlands, the sociology of education can be characterised as a relatively healthy specialism particularly on the empirical and methodological levels. It has a small number of professionals working in the area and has organised its members across universities and research institutes in a solid manner. A few of the sociologists of education have also worked in quite influential public positions (as Minister of Education and Chairman of the National Education Council).

The strong orientation towards educational policy at the beginning of the Dutch sociology of education has been an important incentive for its fruitful development. A strong and classical socio-theoretical tradition was absent, a vacuum in which a practice-oriented empirism was favourably received. Those days are far behind us, however, and there is now reason for concern about the future. A faith in the ability to reconstruct and transform society seems to have vanished from post-industrial society along with the need to have 'social engineers' within arm's reach. A growing empiricism cannot mask the current theoretical emptiness. In fact, the 'poverty of empiricism' is manifesting itself more and more while the demand for theory is clearly increasing among the sociologists of education. 
In contrast to the situation in the UK where Thatcherism and the New Right have created a hostile environment for the sociology of education, the sociology of education in the Netherlands has not stood under heavy critique since the mid-1980s. The peak of its influence has certainly passed, but one cannot speak of the 'marginalisation' which Dale (1992) has used to describe the situation in Britain. In the Netherlands, ideas from the sociology of education continue to have a definite impact on educational practice and policy. An 'osmosis' of sociological insights continues to occur. In my opinion the danger in the Netherlands, however, is one of standstill, fragmentation and isolation from the more general field of sociology.

To begin with the latter, the connection to the basic discipline of sociology is worrisome. Specific sociological themes such as power and inequality or marginalisation and exclusion are encountered too infrequently in the current sociology of education. This undoubtedly stems from the disappearance of the sociology of education as an independent specialism within the departments of sociology at Dutch universities. The current position of the sociology of education within the 'applied' educational sciences has undoubtedly produced accommodation and thinned the sociological content out. This trend can be measured in terms of the number of sociology of education courses (fewer and/or increasingly incorporated under 'interdisciplinary' themes) and the programming of the research in this area. The connection to the basic discipline of sociology has been decidedly weakened.

The former anchoring of the sociology of education in stratification research has also become weaker. Stratification research has gone off in its own direction (also within such international organisations as the International Sociological Association) and, with its dominant theoretical orientation (the explanatory sociology), distanced its educational research from mainstream sociology of education. Questions about the validity of the claims from stratification research with regard to the shifting social inequalities in the Netherlands have in fact created debate among educational sociologists also with regard to the policy aspects of these opinions (Dronkers \& Ultee, 1995).

The strong bond with the educational reform movements of the 1970 s also become looser. Matthijssen $(1971,1982)$ was an important translator of the ideas of Basil Bernstein and Raymond Williams in the Netherlands. The research tradition stemming from this, namely the sociology of the curriculum, and the research within the school classrooms has virtually come to a standstill and thus fostered the disappearance of (micro-)sociology from the area.

The preceding observations lead me to conclude that the stronghold of Dutch educational sociologists has been significantly weakened by theoretical fragmentation, a threat of isolation from the more general field of sociology and little or no theoretical progress. A few of the themes which were current in the debate around the sociology of education a short time ago have now either disappeared or been taken over by other disciplines and thus illustrate this point. The debate with regard to the reproduction of social inequality in and through education has virtually stopped while the phenomenon continues to ask for attention. Critique of policy comes predominantly from educators and (with only a few exceptions) seldom from educational sociologists today. The current debate with regard to the role of the school in the transfer of values and norms is dominated by educators and policy-makers, and the professionalisation of teachers is hardly a theme in the sociology of education at present.

Fortunately, a number of new and important issues appear to be attracting the attention of educational sociologists in the Netherlands. The problems around decentralisation and deregulation are receiving critical discussion and examination (Sleegers \& 
Wesselingh, 1993). The issues of a growing dichotomy in socicty (and the potential creation of a new underclass), participation in society and the establishment of a modern citizenship (and the role of the educational system in this process) are also raising new research themes. Educational sociologists are slowly involving themselves in the debate on the modernisation of society (that is, the transition from welfare state to late-modern society) and the consequences of this transition for the form and content of education. Almost 25 years after Young (1971), 'new directions for the sociology of education' are still appearing.

\section{Acknowledgement}

I am indebted to my colleague Ger Tillekens from the University of Groningen for his valuable suggestions.

Correspondence: Anton Wesselingh, Department of Educational Sciences, Nijmegen University, PO Box 9104, 6500 HE Nijmegen, The Netherlands.

\section{NOTES}

[1] One important school of thought is figurational sociology, inspired by the work of Norbert Elias. Figurational sociology is aimed at the analysis of long-term societal developments from a historical perspective. It is centred in Amsterdam with Abram de Swaan as its most outspoken representative. Another important school of thought is explanatory sociology, aimed at the explanation of social phenomena with-among other things - rational-choice theory and the verification by empirical evidence. The work in this area is concentrated in the International Center for Social Science Theory and Methodology (ICS) in which the universities of Groningen, Utrecht and Nijmegen participate. Several other research groups and individual sociologists are of course active, working from the perspectives of conflict theory, interpretative sociology, etc.

[2] For an earlier account, see Rupp \& Wesselingh (1990) and Peschar \& Wesselingh (1995).

\section{REFERENCES}

Appei, R., Hubers, G. \& MejJer, G. (1976) Sociolinguistiek (Utrecht, Spectrum).

APPEl, R. (1984) Immigrant Children Leaming Dutch. Sociolinguistic and pycholinguistic aspects of second-language acquisition (Dordrecht, ICG printing).

Beekexkamp, G.G. \& Dronkers, J. (1984) De plaats van het onderwijs in de recrutering van president-directeuren, in: J. Dronkers \& F.N. Stokiman (Red.) Nederlandse Elites in Beeld. Recrutering, samenhang en verandering (Deventer, Van Loghum Slaterus).

Bernstern, B. (1971) Class, Codes and Control, Vol. 1. Theoretical Studies towards a Sociology of Language (London, Routledge \& Kegan Paul).

Bernsterv, B. (1977) Class, Codes and Control, Vol. 3. Towards a Theory of Educational Transmissions (rev. edn) (London, Routledge \& Kegan Paul).

Boekholt, P.Th.F.M. \& De Booy, P.T. (1987) Geschiedenis van de School in Nederland (Assen, Van Gorcum). Boli, J., RAMirez, F.O. \& MEYer, J.W. (1985) Explaining the origins and expansion of mass education, Comparative Education Review, 29, pp. 145-169.

Bosmav, R. (1993) Opvoeden in je Eentje. Een onderzoek naar de betekenis van het moedergezin voor de ondeneijskansen van kinderen (Lisse, Swets \& Zeitlinger).

Bourdieu, P. \& Passeron, J.Gl. (1964) Les Héritiers. Les Eludiants et la Culture (Paris, Minuit).

Bourdieu, P. \& Passeron. J.CL. (1970) La reproduction. Eléments pour une théorie du système d'enseignement (Paris, Minuit).

Bourdieu, P. (1979) La distinction. Critique sociale du jugement (Paris, Minuit).

Bourdicu, P. (1984) Homo Academicus (Paris, Minuit).

Bourdieu, P. (1989) La Noblesse d'Etat. Grandes écoles et esprit de corps (Paris, Minuit). 
Calcar, G., Van, SoutendijK, S. \& Tellegen, B. (1968) School, Milieu en Prestatie, in: F. van Heek et al. Het Verborgen Talent. Milieu, schoolkeuze en schoolgeschiktheid (Meppel, Boom).

Colemav,J.S. et al. (1966) Equality of Educational Opportunity (Washington DC, US Government Printing Office).

Colfman, J.S., Hoffer, Th. \& Kilgore, S. (1982) High School Achievement: public catholic and private schools compared (New York, Basic Books).

Coleman, J.S. \& Hoffer, Th. (1987) Public and Private High Schools. The impact of communities (New York, Basic Books).

Costongs J. \& Dronkers, J. (1989) A bet on what works in your school. Paper presented at the International Congress for School Effectiveness, Rotterdam 1989.

DALE, R. (1992) Recovering from a pyrrhic victory? Quality, relevance and impact in the sociology of education, in: M. Amot $\&$ L. Barton (Eds) Voicing Concems. Sociological perspectives on contemporary educational reforms (Wallingford, Triangle Books).

Diederex, J. (1987) Onderwijs en de overgang naar beroep in Nederland, in: G.W. MEIJNEN, A.F.M. Nieuwenhuis \& J.L. Peschar (Red.) Selektie en kwalifikatie in het ondenwijs (Lisse, Swets \& Zeitlinger).

Dronkers, J. (1990) De ontwikkelingen in het schoolloopbaanonderzoek: een terugblik op een decennium, Tijdschrift voor Ondenwijsresearch, 15, pp. 8-22.

Dronkers, J. (1991) Sluipende internationalisering. De groei van het engelstalig onderwijs in Nederland, Sociale Wetenschappen, 34, pp. 171-187.

Dronkers, J. \& DE JONG, U. (1979) Jencks en Fägerlind in a Dutch way: a report on research on the relationship between social background, intelligence, education, occupation and income in the Netherlands, Social Science Information, 18, pp. 761-781.

Dronkers, J. \& BAKKER, B.M.F. (1989) A longitudinal study of the relationship for men between origins, education, marriage, occupation and family income, in: B.F.M. BAKKER, J. DronkERs \& G.W. MEJJEN (Eds) Educational Opportunities in the Welfare State (Nijmegen, ITS/OOMO).

Dronkers, J. \& Ultee, W.C. (Eds) (1995) Verschuivende Ongelijkheid in Nederland. Sociale gelaagdheid en mobiliteit (Assen, Van Grocum).

DiJkstRA, A.B. (1992) De Religieuze Factor. Ondeneijskansen en godsdienst: een vergelijkend onderzoek naar gereformeerd-vrijgemaakte scholen (Nijmegen, ITS/OOMO).

FASE, W. (1994) Ethnic Divisions in Western European Education (Münster, Waxmann).

Ganzeboom, H.B.G. (1988) Leefstïlen in Nederland. Een verkennend onderzoek (Alphen a/d Rijn, Samsom).

Ganzeboom, H.B.G. \& DE GrMAF, N.D. (1990) Cultuurdeelname en opleiding; een analyse van statusgroep-effecten met diagonale referentiemodellen, Mens en Maatschappij, 65, pp. 219-244.

Glebbeek, A.J. \& Mensex, Th. (1986) Opleiding als selectiecriterium een onderzoek onder werkgevers, in: J. Hartog \& J.M.M. Ritzen (Red.) Economische Aspecten van Ondeneijs (Lisse, Swets \& Zeitlinger).

Glebbeek, A. J. (1993) Perspectieven op Loopbanen (Assen, Van Gorcum).

Grotenhuis, H. TE (1993) Bijstandskinderen. Opgroeien aan de rand van de verzorgingsstaat (Amsterdam, Amsterdam Univ. Press).

HALSEY, A.H., Floud, J. \& ANDERson, C.A. (Eds) (1961) Education, Economy and Society. A reader in the sociology of education (New York/London, Free Press/Collier-Macmillan).

HeEk, F. VAN et al. (1968) Het Verborgen Talent. Milieu, Schoolkeuze en Schoolgeschiktheid (Meppel, Boom).

Hoeven-Van Doornum, A. A. (1990) Effecten van Leerlingbeelden en Streefniveaus op Schoolloop-banen (Nijmegen, ITS/OOMO).

HoF, L. VAN 'T \& Dronkers, J. (1993) Differences in educational altainment of children from various groups of recent immigrants in the Netherlands; class, family or migrant culture? Paper presented at the meeting of the ISA Research Committe 'Social stratification and mobility', Durham (North Carolina), August 9-11.

Hoof, J.J. Van (1987) De Arbeidsmarkt als Arena (Amsterdam, SUA).

HoOf, J.J. VAN \& Dronkers, J. (1980) Ondeneijs en Arbeidsmarkt (Deventer, Van Loghum Slaterus).

Huls, H.A. (1982) Taalgebruik in het Gezin en Sociale Ongelijkheid. Een interactioneel sociolinguistisch onderzoek (Nijmegen). Idenburg, PH.J. (1964) Schets van het Nederlandse Schoolwezen (Groningen, Wolters-Noordhoff).

IdENBurg, PH.J. (1971) Theorie van het Ondenwïsbeleid (Groningen, Wolters-Noordhoff).

Jencks, Ghr. et al. (1972) Inequality. A reassessment of the effect of family and schooling in America (New York, Basic Books).

Joxg, MJ. DE (1987) Herkomst, Kennis en Kansen. Allochtone en autochtone leerlingen tijdens de overgang van basis- naar voortgezet onderwijs (Lisse, Swets \& Zeitlinger).

Jong, U. De \& Roeleveld, J. (1989) Public and private secondary schools in Amsterdam, in: B.F.M. BAKKeR, J. Dronkers \& G.W. MeIjnen (Eds) Educational Opportunities in the Welfare State. Longitudinal studies in educational and occupational attainment in the Netherlands (Nijmegen, ITS/OOMO).

Jungbluth, P.L.M. (1985) Verborgen Differentiatie. Leerlingbeeld en ondenerijsaanbod op de basisschool (Nijmegen, ITS). 
KaLMiJn, M. \& BATENBlrg, R. (1986) Reproductie van cultureel en economisch kapitaal op een traditioneel en een Montessori lyceum, Tyjdschrift voor Onderwijsresearch, 11, pp. 149-160.

KLEY, P. VAN DER (1983) Zeg na jij]! Over regels, patronen, beurten selektie en reproductie in het lager onderwijs (Purmerend, Muusses).

Lanrhovex, P. VAN, Bakker, B., Dronkers, J. \& Schyj, H. (1986) Some aspects of school careers in public and non-public primary schools, Tijdschrift voor Ondenwijsresearch, 11, pp. 83-96.

LeEmax, Y. (1985) Onderwijs en etnische verhoudingen, in: J.L. Peschar \& A.A. Wesselingh (Red.) Onderwijssaciologie, een Inleiding (Groningen, Wolters-Noordhoff).

LENDERS, J. (1988) De Burger en de Volksschool Culturele en mentale achtergronden van een onder-wijghenorming in Nederland $1780-1850$ (Nijmegen, SUN).

Lenders, J., Mazeland, H. \& Van Nielwstadt, M. (1978) Taal, Arbeidersklasse en Ongelijkheid. Een kritiek op de theoretische en prakiische veronderstellingen van de sociolinguistiek (Amsterdam, Van Gennep).

Lisdex, F.J. (1991) Adolescent Lifezworld. Theoretical and empirical orientations in socialization processes of Dutch youth (Amsterdam/Lisse, Swets \& Zeitlinger).

Matthijssen, M.A.J.M. (1958) De Intellectuele Emancipatie der Katholieken (Assen, Van Gorcum).

Mntтijjssex, M.A.J.M. \& Sonnemans, G.J. (1958) Schoolkeuze en Schoolsucces bij VHMO en ULO in Noord-Brabant (Tilburg, Zwijssen).

Matthijssex, M.A.J.M. (1971). Klasse-Onderwijj. Sociologie van het onderwijs(Deventer, Van Loghum Slaterus).

Matthijssex, M.A.J.M. (1982) De Elite en de Mythe. Een sociologische analyse van strijd om onderwijsverandering (Deventer, Van Loghum Slaterus).

Matthijssex, M.A.J.M. \& Vervoort, C.E. (Eds) (1969) Education in Europell'Education en Europe (Den Haag, Mouton).

Meesters, M.J. (1992) Loopbanen in het Onderwijs en op de Arbeidsmarkt (Nijmegen, ITS/OOMO).

MeIJnen, G.W. (1977) Maatschappelijke Achtergronden van Intellectuele Ontwikkeling (Groningen, Wolters-Noordhoff).

MFIJNEN, G.W. (1984) Van Zes tot Twaalf (Harlingen, Flevodruk).

Neder landse Sociologische Verexiging (NSV) (1965) Naar een Sociologie van Onderwijs en Opvoeding (Den Haag, Mededelingen nr. 10).

PARkix, F. (1971) Class Inequality and Political Order (London, MacGibbon \& Kee).

Peschno, J.L. (1975) Milieu, School en Beroep; een achteraf-experiment over de periode 1958-1973 naar de invloed van het sociaal milieu op school-en beroepsloopbaan (Groningen, Konstapel).

Peschar, J. L. (Ed.) (1990) Social Reproduction in Eastem and Western Europe (Nijmegen, ITS/OOMO).

Peschar, J.L. \& Wesselingh, A.A. (1995) Ondeneijssociologie (Groningen, Wolters-Noordhoff).

Ploeg, S.W. VAN Der (1993) The Expansion of Secondary and Tertiary Education in the Netherlands (Nijmegen, ITS/OOMO).

Ramirez, F.O. \& Boli, J. (1987) The political construction of mass schooling, Sociology of Education, 60, pp. 2-17.

Rupp, J.C.C. \& DE LANGe, R. (1989) Social order, cultural capital and citizenship. An essay concerning educational status and educational power versus comprehensiveness of elementary schools, Sociological Review, 49, pp. 660-695.

RUPP, J.C.C., WALET, M. \& VAN WOLPUT, B. (1990) Cultureel versus economisch gerichte basisscholen en hun publiek, Sociologische Gids, 37, pp. 335-350.

RUPP, J.C.C. \& WESSELINGH, A.A. (1990) Education, social inequality and citizenship. An overview of 25 years of research and theory development in the Netherlands, Netherlands' Joumal of Social Scionces, 26, pp. 112-132.

Scheerexs, J. (1989) Wat Maakt Scholen Effectief? Samenvalting en analyse van onderzoeksresultaten (Den Haag, SVO).

Schijf, H. \& Dronkers, J. (1989) Groningen Revisited; neighbourhoods and educational attainment 1960-1971. Paper presented for the ISA Research Committee on Social Stratification and Mobility, Utrecht University, The Netherlands, 26-29 April.

SleEgers, P.C. \& Wesselivgh, A.A. (1993) Decentralisation in education; a Dutch study, Intemational Studies in Sociology of Education, 3, pp. $49-67$.

SivaAn, A. DE (1988) In Care of the State (Oxford, Blackwell).

TurNer, R. (1986) Equality (London, Horwood, Chichester and Tavistock).

UlTEE, W.C. (1984) The ups and downs of the mobility problem in the Dutch and international sociology, in: B.F.M. Bakker, J. Dronkers \& H.B.G. Ganzeboom (Eds) Social Stratification in the Netherlands (Amsterdam, SISWO).

VELD, TH. (1987) Volksonderwijs en Leerplicht. Een historisch sociologisch onderzoek naar het ontstaan van de Nederlandse leerplicht 1860-1900 (Delft, Eburon).

VERvoORT, C.E. (1968) Gezin en Schoolkeuze bij Handarbeiders (Leiden, Sociologisch Instituut).

VERvoORT, C.E. (1981) Interventiestaat, onderwijs en ongelijkheid, in: P. V.D. KLEY et al. (Red.) Interventiestaat en Ongelijkheid (Nijmegen, Sociologisch Instituut). 
Vliegex J. M. \& De Jong, U. (1981) Ondereijs in Nederland. Monografien Volkstelling 1971, nr. 12 (Den Haag, Staatsuitgeverij).

VREeBURG, B. (1993) Idenititeit en het Verschil. Levensbeschouwelijke vorming en het Nederlands voortgeet onderwijs (Amersfoort, De Horstink).

Weber, M. (1956) Wirtschaft und Gesellschaft (Tübingen, Mohr).

Wesselivgh, A.A. (Red.) (1979) School en Ongelijkheid. Hoe het onderwïs bijdraagt aan het handhaven van ongelijkheid in de maatschappij (Nijmegen/Amsterdam, Link).

Wesselingh, A.A. (1982) Sociology of education in the Netherlands: situations, development, debates, British Joumal of Sociology of Education, 3, pp. 319-329.

WesseI.Ngh, A.A. (1985) Ondereïs en Reproductie van Maatschappelijke Ongelijkheid 1975-1985 (Nijmegen, ITS/ OOMO).

Wolthuis, J. (1987) De sociologie von Margaret Archer, Mens en Maatschappij, 62, pp. 270-288.

Young, M.F.D. (Ed.) (1971) Knowledge and Control. New directions for the sociology of education (London, Collier Macmillan). 